\author{
Karen M. Lauridsen*
}

\title{
Definition af kompetenceniveauer i fremmedsprog inden for en falles europæisk referenceramme
}

\begin{abstract}
The definition of levels of foreign language competence is anything but unambiguous. There is thus a need for a more fine-tuned framework of reference, within which the different levels of competence may be described. In this article the Common European Framework of Reference, developed under the auspices of the Council of Europe, will be briefly described as will DIALANG, a web-based diagnostic testing system developed in accordance with the common European framework. Finally, the strengths and weaknesses as well as the perspectives for future use of these new tools will be discussed.
\end{abstract}

Definition af kompetenceniveauer i fremmedsprog er langt fra nogen entydig størrelse. Ved optagelse på et universitet i udlandet kræves fx i de fleste tilfælde en bestemt score ved et af de store kulturinstitutters prøver (British Council, Goethe Institut, TOEFL eller lignende); i andre sammenhænge anvendes betegnelser som begynderniveau, mellemniveau og avanceret niveau.

Kulturinstitutterne prøver den enkeltes færdigheder inden for nogle nærmere definerede områder, mens begynder-, mellem- og avanceret niveau er gængse betegnelser for de niveauer, der undervises på i en given sammenhæng, uden at det reelt siger noget om, hvilket niveau den enkelte elev rent faktisk befinder sig på, når undervisningsforløbet er afsluttet. Det samme gælder for de betegnelser, der anvendes i den danske gymnasieskole, hvor undervisningen er defineret som værende på henholdsvis A-, B-, eller C-niveau inden for et givet fag, det vil sige, den fører frem til henholdsvis A-, B- eller C-niveau i det pågældende fag.

\footnotetext{
* Karen M. Lauridsen

Handelshøjskolen i Arhus

Fuglesangs alle 4

DK-8210 Aarhus $V$

kml@asb.dk
} 
Meget taler således for, at der er behov for at introducere en anden og mere detaljeret form for skala til at beskrive både det niveau, der er målet for undervisningen, og det niveau, som den enkelte opnår som resultat af denne undervisning. Nedenfor beskrives en sådan skala, nemlig Europarådets fælles referenceramme, samt et system til diagnostiske tests af sprogfærdighed på 14 forskellige europæiske sprog, DIALANG. Endvidere beskrives, hvorledes Europarådets referenceramme anvendes i DIALANG, og det diskuteres, hvilke muligheder henholdsvis begrænsninger der er i de to systemer, og hvor der stadig er behov for yderligere udvikling eller afprøvning af systemerne.

\section{Europarådets falles referenceramme}

Europarådets fælles referenceramme ${ }^{1}$ (Common European Framework of Reference) kan fungere som en fælles basis for udviklingen af undervisningsbekendtgørelser, undervisningsvejledninger, retningslinier for eksamen, tilrettelæggelse af undervisningsmateriale mv. i hele Europa. Den beskriver, hvad fremmedsprogslørnere ${ }^{2}$ skal kunne for at være i stand til at anvende et givet fremmedsprog på en hensigtsmæssig måde i en given sammenhæng, samt hvilken viden og hvilke færdigheder de skal udvikle for at kunne gøre dette. Den fælles referenceramme udgør således et grundlag for at beskrive formål, indhold og metoder og bidrager dermed til at styrke gennemsigtigheden i kursusplaner og de kvalifikationer, de enkelte kurser leder frem til.

Med objektive kriterier til at beskrive og definere de forskellige sprogfærdighedsniveauer inden for en fælles referenceramme er det enklere at sammenligne kvalifikationer, som de enkelte lørnere har opnået $i$ forskellige sammenhænge, eksempelvis i forskellige skoletraditioner i forskellige lande, ligesom det er enklere at samarbejde på tværs af traditionelle geografiske, kulturelle eller sproglige grænser.

Europarådets sprogpolitik skal naturligvis vurderes inden for den generelle politiske ramme, som eksisterer for Europarådets arbejde. Her

1 http://www.coe.int/T/E/Cultural_Co-operation/education/Languages/ Language Policy/Common Framework_of Reference/cadre.asp\#TopOfPage (Council of Europe / Europarådet 2001).

2 Den lidet danske term lørner anvendes i mangel af bedre som betegnelse for den person, der skal lære (i dette tilfælde fremmedsprog). 
skal blot nævnes ønsket om at synliggøre de sproglige ressourcer, som det enkelte menneske allerede besidder, samt ønsket om så effektivt som muligt at udvikle hans / hendes sproglige viden og færdigheder i et flersproget og flerkulturelt Europa.

\subsection{Plurilingvistisk tilgang}

Den fælles referenceramme tager udgangspunkt i en plurilingvistisk tilgang, der bygger på den antagelse, at det enkelte menneskes sproglige erfaring udvides fra modersmålet i hjemmet til modersmålet i samfundet generelt og derefter til et eller flere fremmede sprog i deres respektive kulturelle kontekster. I denne proces holder lørneren ikke disse sprog og kulturer strengt adskilt, men opbygger en kommunikativ kompetence, som al viden om og erfaring med sprog bidrager til, og inden for hvilken sprogene relaterer sig til hinanden og interagerer. I forskellige situationer kan den enkelte således trække på forskellige aspekter af denne samlede kompetence for at bidrage til en så effektiv kommunikation som muligt.

Med dette udgangspunkt betragtes formålet med sprogundervisning ikke blot som det at mestre et eller flere fremmedsprog med den modersmålstalende som ideal. I stedet bliver formålet at udvikle et bredt sprogligt repertoire, som den enkelte lørner kan videreudvikle på forskellig vis. For at dette kan lykkes, skal lørneren naturligvis ikke blot lære at lære, det vil sige lære at tilegne sig fremmede sprog og lære at reflektere over - og dermed justere og optimere - selve læreprocessen; han skal også gøres bevidst om de forskellige niveauer i et flerdimensionalt system, som han kan eller skal tilegne sig. Og det er i denne sammenhæng, at Europarådets fælles referenceramme og dertil knyttede diagnostiske test samt en europæisk sprogportefølje kan spille en betydelig rolle.

\subsection{Den falles referencerammes rolle}

Med det dokument, som Europarådet fremlagde i forbindelse med det europæiske sprogår i 2001, er grundstenen lagt til en fælles europæisk referenceramme, som kan

$\checkmark$ fremme samarbejde mellem uddannelsesinstitutioner i forskellige lande

$\checkmark$ udgøre grundlaget for gensidig anerkendelse af sproglige kvalifikationer 
$\checkmark$ hjælpe lørnere, undervisere, kursusudviklere, eksaminatorer og censorer samt de institutionelle, nationale og internationale myndigheder, som har ansvaret for undervisning og udprøvning, til at skabe en fælles platform og koordinere deres aktiviteter.

Referencerammen kan således anvendes til at

$\checkmark$ planlægge sprogkurser eller længere uddannelsesprogrammer på alle niveauer

$\checkmark$ planlægge certificering af sproglige færdigheder

$\checkmark$ planlægge selvstændig læring.

Kurser eller programmer, og en eventuel certificering af disse, kan være

$\checkmark$ globale: de bidrager til, at lørneren gør fremskridt og opnår et bestemt niveau på alle sprogfærdighedens og den interkulturelle kompetences dimensioner

$\checkmark$ modulære: de bidrager til, at lørnerens færdighed forbedres inden for et bestemt område med et bestemt formål

$\checkmark$ vægtede: de understøtter læring inden for bestemte områder og bidrager dermed til udviklingen af en bestemt profil, hvor lørneren opnår et højere niveau inden for visse vidensområder eller visse færdigheder end inden for andre

$\checkmark$ partielle: de omfatter udelukkende bestemte færdigheder og beskæftiger sig ikke med de øvrige.

Europarådets fælles referenceramme er konstrueret således, at dette kan lade sig gøre, jf. afsnit 2 nedenfor. Omvendt gælder det, at det system, som er udviklet, og hvis grundlæggende principper bliver beskrevet nedenfor, fortsat kan / skal udvikles for at det kan stille det tilstrækkelige og nødvendige beskrivelsesapparat til rådighed, så man kan udvikle rammerne for og indholdet i fremmedsprogstilegnelsesprocessen. De dimensioner og de eksemplariske deskriptorer, som er anvendt, skal videreudvikles, ikke mindst når det gælder fremmedsprogsundervisning og fremmedsprogstilegnelse inden for højere uddannelse. Desuden er beskrivelsesapparatet (herunder deskriptorerne) og den dertil knyttede terminologi på nuværende tidspunkt primært udviklet på engelsk og nogle få andre sprog og er kun i begrænset omfang til rådighed på fx dansk. Der ligger således et stort arbejde forude, som ikke udelukkende drejer sig om en oversættelse fra engelsk, men også en generel tilpasning til dansk. 
Det har været et grundlæggende princip i udviklingen af referencerammen, at den skal omfatte så bred en vifte af viden, færdigheder og anvendelsesområder som overhovedet muligt uden dog at forsøge at være altomfattende (en umulig opgave). Men med den struktur, som er valgt, er det til gengæld muligt løbende at videreudvikle enkeltelementer eller moduler, om man vil.

Et andet princip er, at systemet skal være transparent således, at al information er klart og eksplicit formuleret. Endelig skal det være sammenhængende, det vil sige uden indre modsætninger, så det kan bruges til

$\checkmark$ at identificere behov

$\checkmark$ at formulere målsætninger

$\checkmark$ at definere indhold

$\checkmark$ at udvælge eller udvikle materiale

$\checkmark$ at etablere undervisnings- / læringsprogrammer

$\checkmark$ at anvende forskellige undervisnings- og læringsmetoder

$\checkmark$ at evaluere, teste og bedømme program, materiale og metode såvel som lørnerens konkrete resultater.

I det følgende beskrives Europarådets fælles referenceramme for kommunikativ kompetence og de dertil knyttede sproglige og interkulturelle kommunikationsfærdigheder.

\section{Fælles referenceramme for færdighedsniveauer}

De forskellige niveauer i en sådan fælles referenceramme bør som udgangspunkt være kontekst-fri, altså ikke specifikt relatere sig til en bestemt kursus- eller skoleform. Samtidig skal den i princippet være kontekstrelevant for enhver form for fremmedsprogundervisning og -læring. Den metode, der er anvendt i udviklingen af referencerammen med en kombination af intuitive, kvalitative og kvalitative metoder, skulle sikre, at niveauinddelingerne er relevante og brugervenlige, og at de har en indbygget robusthed. ${ }^{3}$

Referencerammen omfatter tre dimensioner: en vertikal skala af sprogfærdighedsniveauer, en horisontal dimension af kommunikative

3 For nærmere angående dette, se http://www.coe.int/T/E/Cultural_Co-operation/ education/Languages/Language_Policy/Common_Framework_of_Reference/ cadre.asp\#TopOfPage, s. $21 \mathrm{f}$. 
aktiviteter og sproglige kompetencer og en tredje dimension, der angiver domæne.

\subsection{Den vertikale skala af sprogfærdighedsniveauer}

Den vertikale dimension omfatter tre grundniveauer, der kan siges at svare til den kendte skelnen mellem begynderniveau, mellemniveau og avanceret niveau. Disse tre er hver især underinddelt $i$ to niveauer i den globale skala, hvorved der fremkommer i alt seks niveauer:

\begin{tabular}{|c|c|c|}
\hline \multirow[t]{2}{*}{$\begin{array}{l}\text { Avanceret } \\
\text { niveau } \\
\text { (Proficient } \\
\text { User) }\end{array}$} & C2 & $\begin{array}{l}\text { Kan uden besvær forstå stort set alt, hvad han/hun hører eller læser. Kan opsum- } \\
\text { mere information fra forskellige talte og skrevne kilder og dermed rekonstruere } \\
\text { argumenter og beretninger i en sammenhængende præsentation. Kan udtrykke sig } \\
\text { spontant, meget flydende og præcist, herunder differentiere finere betydningsnu- } \\
\text { ancer i komplekse sammenhænge. }\end{array}$ \\
\hline & C1 & $\begin{array}{l}\text { Kan forstå en bred vifte af krævende, længere tekster og forstå implicit betydning. } \\
\text { Kan udtrykke sig flydende og spontant uden åbenlyst at skulle søge efter passende } \\
\text { udtryk. Kan anvende sproget fleksibelt og effektivt i sociale, akademiske og pro- } \\
\text { fessionelle sammenhænge. Kan producere klar, velstruktureret og detaljeret tekst } \\
\text { om komplekse emner, der demonstrerer lørnerens evne til bevidst at benytte en } \\
\text { bestemt struktur, bestemte konnektorer eller andre kohæsive midler. }\end{array}$ \\
\hline \multirow[t]{2}{*}{$\begin{array}{l}\text { Mellem- } \\
\text { niveau } \\
\text { (Independent } \\
\text { User) }\end{array}$} & B2 & $\begin{array}{l}\text { Kan forstå hovedpunkterne i en kompleks tekst om både konkrete og abstrakte } \\
\text { emner, herunder tekniske diskussioner inden for sit eget faglige specialiserings- } \\
\text { område. Kan interagere med en vis fluency og spontanitet, som gør almindelig } \\
\text { interaktion med modersmålstalende mulig, uden at det bliver anstrengende for } \\
\text { nogen af parterne. Kan producere klar, detaljeret tekst om en bred vifte af emner } \\
\text { og forklare et givet synspunkt vedr. et diskussionsemne, herunder de fordele og } \\
\text { ulemper der er ved forskellige muligheder. }\end{array}$ \\
\hline & B1 & $\begin{array}{l}\text { Kan forstå hovedpunkterne i klart standardinput om velkendte forhold, som man } \\
\text { ofte støder på i forbindelse med arbejde, skole, fritidsaktiviteter, mv. Kan håndtere } \\
\text { de fleste situationer, som kan forudses i forbindelse med at rejse i et land, hvor } \\
\text { sproget tales. Kan producere simpel, sammenhængende tekst om emner, som enten } \\
\text { er velkendte eller omhandler lørnerens personlige interesser. Kan beskrive oplevel- } \\
\text { ser eller begivenheder, personlige drømme, håb og ambitioner og kort angive be- } \\
\text { grundelser og forklaringer i forbindelse med (egne) meninger og planer. }\end{array}$ \\
\hline \multirow[t]{2}{*}{$\begin{array}{l}\text { Begynder- } \\
\text { niveau } \\
\text { (Basic } \\
\text { User) }\end{array}$} & A2 & $\begin{array}{l}\text { Kan forstå sætninger og ofte anvendte udtryk, der relaterer sig til områder af umid- } \\
\text { delbar relevans (fx meget basal personlig information, information om familiefor- } \\
\text { hold, indkøb, lokal geografi, arbejde). Kan kommunikere i enkle og rutinemæssige } \\
\text { sammenhænge, der kræver en enkel og direkte udveksling af information om } \\
\text { kendte og rutinemæssige forhold. Kan i enkle udtryk beskrive hans/hendes bag- } \\
\text { grund, umiddelbare miljø og dagligdags forhold. }\end{array}$ \\
\hline & A1 & $\begin{array}{l}\text { Kan forstå og anvende kendte dagligdagsudtryk og meget basale konstruktioner } \\
\text { som skal opfylde helt konkrete kommunikationsbehov. Kan introducere sig selv } \\
\text { eller andre og kan stille og svare på spørgsmål om personlige detaljer, så som hvor } \\
\text { han/hun bor, mennesker han/hun kender eller ting, som han/hun ejer. Kan inter- } \\
\text { agere på en enkel måde, hvis den anden part taler langsomt og tydeligt og er ind- } \\
\text { stillet på at hjælpe. }\end{array}$ \\
\hline
\end{tabular}

Skema 1: Den globale skala for færdighedsniveauer ${ }^{4}$

4 Forfatterens oversættelse til dansk efter engelsk forlæg. Skemaerne 2-4 nedenfor er ligeledes forfatterens oversættelse. 
Som det ses, er A1 det laveste niveau, mens C2 er det højeste niveau. Det forudsættes, at en lørner på eksempelvis C1-niveau mestrer niveauerne $\mathrm{A}$ og B, mens en lørner på B1-niveau mestrer det, som er nævnt under A. Det skal understreges, at trinene mellem de enkelte niveauer ikke nødvendigvis er lige store, og at det for den enkelte lørner kan tage længere eller kortere tid at komme fra sit nuværende til det næste niveau, end det er tilfældet med det næste trin igen. Dette vil være individuelt og vil afhænge af en række faktorer, som fx indlæringsintensitet, tid, geografisk placering (i eller uden for det land, hvor sproget tales) mv. Fælles for alle beskrivelserne er dog, at de som nævnt tager udgangspunkt i den individuelle lørner og hans / hendes personlige baggrund, undervisningseller arbejdssituation og kulturelle kontekst.

\subsection{Den horisontale dimension: færdighedsområder}

I den horisontale dimension skelnes mellem forståelsesfærdigheder, lytte og læse, og produktionsfærdigheder, tale (talt interaktion og talt produktion) samt skrive. Derved fremkommer en matrice med 6 x 5 sæt deskriptorer, der igen kan nuanceres yderligere. I skema 2 nedenfor følger således et eksempel på to af disse færdighedsområder, nemlig læse- og skrivefærdigheder på A1-C2 niveau: ${ }^{5}$

\footnotetext{
5 Forfatterens oversættelse til dansk efter engelsk forlæg, http://www.coe.int/T/E/ Cultural Co-operation/education/Languages/Language Policy/ Common_Framework_of_Reference/cadre.asp\#TopOfPage, s 26-27; oprindeligt produceret $i$ et forskningsprojekt beskrevet i Appendix B, s. 217-225.
} 


\begin{tabular}{|c|c|c|}
\hline & Læsefærdighed & Skrivefærdighed \\
\hline $\mathrm{C2}$ & $\begin{array}{l}\text { Jeg kan uden besvær læse stort set alle former for } \\
\text { skrevet sprog, herunder abstrakte og strukturelt } \\
\text { eller sprogligt komplekse tekster som eksempel- } \\
\text { vis manualer, specialartikler og litterære værker. }\end{array}$ & $\begin{array}{l}\text { Jeg kan skrive klar, letflydende tekst i en passen- } \\
\text { de stil. Jeg kan skrive komplekse breve, rapporter } \\
\text { og artikler, som fremlægger et sagsforhold med } \\
\text { en effektiv logisk struktur, der hjælper modtage- } \\
\text { ren til at bemærke og huske vigtige punkter. Jeg } \\
\text { kan skrive resumeer og anmeldelser af professio- } \\
\text { nelle eller litterære værker. }\end{array}$ \\
\hline C1 & $\begin{array}{l}\text { Jeg kan forstå lange og komplekse faktuelle og } \\
\text { litterære tekster og opfatte stilforskelle i disse. } \\
\text { Jeg kan forstå specialartikler og længere tekniske } \\
\text { instruktioner, selv når de ikke falder inden for mit } \\
\text { fagområde. }\end{array}$ & $\begin{array}{l}\text { Jeg kan udtrykke mig i klar, velstruktureret tekst, } \\
\text { hvori jeg udtrykker synspunkter i nogen detalje- } \\
\text { ringsgrad. Jeg kan skrive om komplekse emner i } \\
\text { et brev eller en rapport, hvori jeg understreger, } \\
\text { hvad jeg anser for at være de vigtigste punkter. } \\
\text { Jeg kan vælge en stil, som passer til den givne } \\
\text { læser eller målgruppe. }\end{array}$ \\
\hline B2 & $\begin{array}{l}\text { Jeg kan læse artikler og rapporter om samtidspro- } \\
\text { blemer, hvor forfatteren har valgt bestemte hold- } \\
\text { ninger eller synspunkter. Jeg kan forstå moderne, } \\
\text { litterær prosa. }\end{array}$ & $\begin{array}{l}\text { Jeg kan skrive klar, detaljeret tekst om en bred } \\
\text { vifte af emner, som interesserer mig. Jeg kan } \\
\text { skrive et essay eller en rapport, som formidler } \\
\text { information eller giver begrundelser for eller } \\
\text { imod et bestemt synspunkt. Jeg kan skrive breve, } \\
\text { der belyser, hvad begivenheder eller oplevelser } \\
\text { betyder for mig personligt. }\end{array}$ \\
\hline B1 & $\begin{array}{l}\text { Jeg kan forstå tekster, der primært består af ofte } \\
\text { anvendt dagligdags sprog eller sprog, der relate- } \\
\text { rer sig til mit job. Jeg kan forstå beskrivelsen af } \\
\text { begivenheder, følelser og ønsker i personlige } \\
\text { breve. }\end{array}$ & $\begin{array}{l}\text { Jeg kan skrive enkel, sammenhængende tekst om } \\
\text { emner, som er velkendte eller af personlig inte- } \\
\text { resse for mig. Jeg kan skrive personlige breve, } \\
\text { der beskriver oplevelser eller indtryk. }\end{array}$ \\
\hline A2 & $\begin{array}{l}\text { Jeg kan læse meget korte, enkle tekster. Jeg kan } \\
\text { finde specifik, forudsigelig information i enkelt } \\
\text { dagligdags materiale som fx annoncer, brochurer, } \\
\text { menukort og køreplaner, og jeg kan forstå korte, } \\
\text { enkle personlige breve. }\end{array}$ & $\begin{array}{l}\text { Jeg kan skrive korte, enkle noter og beskeder in- } \\
\text { den for områder af umiddelbar relevans. Jeg kan } \\
\text { skrive enkle, personlige breve som fx takkebreve. }\end{array}$ \\
\hline A1 & $\begin{array}{l}\text { Jeg kan forstå velkendte navne, ord og meget } \\
\text { enkle sætninger, fx på opslag og plakater eller i } \\
\text { kataloger. }\end{array}$ & $\begin{array}{l}\text { Jeg kan skrive et kort, enkelt postkort, fx fra et } \\
\text { ferieophold. Jeg kan udfylde skemaer med per- } \\
\text { sonlige oplysninger, fx skrive mit navn, nationa- } \\
\text { litet og adresse på et hotels registreringsformular. }\end{array}$ \\
\hline
\end{tabular}

Skema 2: Læse- og skrivefærdigheder på A1 til C2 niveau

Det oprindelige skema har også deskriptorer for de tre sidste færdighedsområder, lytte, talt interaktion og talt produktion. Som det fremgår, er der i denne matrice tale om "jeg-kan" deskriptorer. Disse anvendes, når lørneren skal bedømme niveauet i sine egne færdigheder. Sådanne bedømmelser medvirker naturligvis også til at gøre lørneren bevidst om sine egne færdigheder, om hvorledes man kan skelne mellem dem, og hvilket niveau han/hun befinder sig på. Deskriptorerne her kan selvsagt ret nemt omskrives til generelle statements om en gruppe af lørnere, hvis man fx skal beskrive niveauet $\mathrm{i}$ et bestemt kursus eller selve kursets indhold.

Man kan naturligvis også vende skemaet om, så at sige, og fx give en global beskrivelse af alle færdigheder på eksempelvis $\mathrm{C} 1$ niveau: 


\begin{tabular}{|l|l|}
\hline Lyttefærdighed & $\begin{array}{l}\text { Jeg kan forstå længere tale, også når det ikke er klart struktureret, og når } \\
\text { relationer kun er antydet og ikke eksplicit signalleret. Jeg kan forstå TV- } \\
\text { programmer og film uden ret meget besvær. }\end{array}$ \\
\hline Læsefærdighed & $\begin{array}{l}\text { Jeg kan forstå lange og komplekse faktuelle og litterære tekster og opfatte } \\
\text { stilforskelle i disse. Jeg kan forstå specialartikler og længere tekniske } \\
\text { instruktioner, selv når de ikke falder inden for mit fagområde. }\end{array}$ \\
\hline Talt interaktionsfærdighed & $\begin{array}{l}\text { Jeg kan udtrykke mig flydende og spontant uden i påfaldende grad at lede } \\
\text { efter udtrykkene. Jeg kan bruge sproget fleksibelt og effektivt til sociale og } \\
\text { professionelle formål. Jeg kan formulere ideer og meninger (holdninger) } \\
\text { præcist og på en sikker måde relatere mine bidrag til de øvrige diskus- } \\
\text { sionsdeltageres. }\end{array}$ \\
\hline Talt produktionsfærdighed & $\begin{array}{l}\text { Jeg kan præsentere klare, detaljerede beskrivelser af komplekse emner, } \\
\text { hvori jeg integrerer underemner, udvikler bestemte pointer og runder af } \\
\text { med en passende konklusion. }\end{array}$ \\
\hline Skrivefærdighed & $\begin{array}{l}\text { Jeg kan udtrykke mig i klar, velstruktureret tekst, hvori jeg udtrykker syns- } \\
\text { punkter i nogen detaljeringsgrad. Jeg kan skrive om komplekse emner i et } \\
\text { brev eller en rapport, hvori jeg understreger, hvad jeg anser for at være de } \\
\text { vigtigste punkter. Jeg kan vælge en stil, som passer til den givne læser } \\
\text { eller målgruppe. }\end{array}$ \\
\hline
\end{tabular}

Skema 3: Alle fem færdigheder på C1 niveau

Som allerede nævnt, kan de forskellige færdigheder beskrives i yderligere detaljer ud fra forskellige synspunkter som $\mathrm{fx}$, hvad undervisningsmaterialet skal indeholde, hvad adgangsniveauet skal være for et bestemt kursus (hvilke færdigheder man skal beherske for at kunne deltage i det pågældende kursus), eller for at angive, hvad man kan forvente at have lært ved afslutningen af et kursus. Deskriptorerne i skema 3 ovenfor kan således eksempelvis nuanceres med kvalitative aspekter som nedenstående, der alle refererer til talt sprog på $\mathrm{C} 1$ niveau:

\begin{tabular}{|l|l|}
\hline Omfang & $\begin{array}{l}\text { Behersker sprog i en sådan bredde, at det tillader ham/hende at vælge en formulering til at } \\
\text { udtrykke sig klart og på en passende måde om en lang række generelle, akademiske, } \\
\text { professionelle eller fritidsemner uden at skulle indskrænke, hvad han/hun ønsker at sige. }\end{array}$ \\
\hline Præcision & $\begin{array}{l}\text { Holder hele tiden en høj grad af grammatisk præcision; fejl er sjældne og vanskelige at er- } \\
\text { kende, og de bliver som oftest rettet med det samme, når de faktisk forekommer. }\end{array}$ \\
\hline Fluency & $\begin{array}{l}\text { Kan stort set uden besvær udtrykke sig flydende og spontant. Kun et vanskeligt emne for- } \\
\text { hindrer et naturligt sprogligt flow. }\end{array}$ \\
\hline Interaktion & $\begin{array}{l}\text { Kan vælge et passende udtryk fra en række diskursfunktioner, som han/hun allerede har til } \\
\text { rådighed, til at beholde eller få ordet og til at relatere sine egne bidrag til de andre diskus- } \\
\text { sionspartneres. }\end{array}$ \\
\hline Kohærens & $\begin{array}{l}\text { Kan producere klar og letflydende tale, der viser en bevidst brug af en bestemt struktur, be- } \\
\text { stemte konnektorer og andre kohæsive midler. }\end{array}$ \\
\hline
\end{tabular}

Skema 4: Kvalitative aspekter af den talte sprogfærdighed på C1 niveau 


\subsection{Domæner}

Som allerede nævnt er det et grundlæggende princip, at den fælles europæiske referenceramme skal være kontekstrelevant. Det skyldes naturligvis, at al sproglig og kommunikativ aktivitet finder sted inden for et givet domæne, som kan være mere eller mindre specialiseret. Inden for referencerammen skelnes mellem det offentlige domæne, det private domæne, det uddannelsesmæssige domæne og det arbejdsmæssige domæne. Som det allerede er fremgået af både de generelle og de mere specifikke og kvalitative deskriptorer i skemaerne ovenfor, tages der for hvert enkelt niveau udgangspunkt i den enkelte lørner. Alle vil naturligvis have brug for at kommunikere inden for alle de nævnte domæner til en vis grad, men omfanget og specialiseringsgraden vil variere fra lørner til lørner, eller fra lørnergruppe til lørnergruppe, og jo højere færdighedsniveauer der er tale om, jo mere relevant forekommer det at kontekstualisere uddannelsesprogrammet til bestemte domæner for en eller flere af de relevante færdigheder. Dette gælder ikke mindst inden for højere uddannelse, hvad enten det drejer sig om korte, mellemlange eller lange videregående uddannelser. En sådan kontekstualisering sker naturligvis allerede, i hvert fald i et vist omfang, også selv om programmet endnu ikke er defineret i forhold til den fælles referenceramme.

For eksempel vil undervisningen i engelsk på en ingeniørhøjskole kunne defineres inden for det private og offentlige domæne for den mere generelle del samt inden for en række tekniske domæner. Det er så op til den enkelte uddannelse at definere, hvilket niveau der er målsætningen, og om det skal omfatte alle fem færdigheder eller kun nogle af dem, jf. distinktionen mellem globale og vægtede programmer i 1.2 ovenfor.

Mange vil spørge sig selv, om det ikke er det, som vi altid har gjort på uddannelsesinstitutionerne. Jo, det er det, men kun til en vis grad. Lad mig give et par eksempler. Den fælles referenceramme forudsætter for det første, at kommunikationen foregår i en kontekst og dermed implicit også, at den enkelte besidder eller udvikler genrebevidsthed og fornemmelse for diskursfællesskabers skrevne og uskrevne love. Ikke desto mindre bliver mange elever i folkeskolen eller gymnasiet bedt om at skrive en boganmeldelse eller en filmanmeldelse, både på deres modersmål og på fremmedsprog. Det er for mig et eksempel på, at underviserne i tilrettelæggelsen af undervisningen og undervisningsmateriale ikke har taget hensyn til disse forhold. En film- eller en boganmeldelse kræver både en 
ikke-sproglig professionel baggrund og en meget veludviklet sproglig og kommunikativ produktionsfærdighed, som hverken folkeskoleelever eller gymnasieelever besidder eller behersker, jf. at netop denne genre også er nævnt som en C2 skrivefærdighed (Jeg kan skrive resumeer og anmeldelser af professionelle eller littercere varker) i skema 1 ovenfor. I tilrettelæggelsen af al undervisning skal man naturligvis tage hensyn til både den sprogligt-kommunikative og den ikke-sproglige viden og de færdigheder, som lørneren eller lørnergruppen besidder. ${ }^{6}$

Selv om studieordninger og-vejledninger gennem de senere år mange steder er blevet ekspliciteret til i højere grad at fokusere på formålet med de enkelte moduler og deres læringsmål, er der efter min opfattelse stadig behov for forbedringer. Og man skal i den forbindelse huske på, at den studerende eller den færdige kandidat ikke blot skal kunne dokumentere sine kvalifikationer i en dansk kontekst, men ofte vil have brug for at dokumentere disse uden for Danmarks grænser. Her ville det være en meget stor hjælp, hvis han/hun kunne referere til den fælles referencerammes niveauer og færdighedsområder og til bestemte domæner, fordi det vil være meget enklere at sammenligne den danske kandidats kvalifikationer med de krav, der stilles på en udenlandsk uddannelsesinstitution eller på en potentiel arbejdsplads. Dette gælder både for kandidater, der har fremmedsprog som genstandsområde, og for kandidater med andre fagområder, som skal kunne kommunikere i en ikke-dansk kontekst.

Det er en generel tendens i europæisk uddannelse, at man i stedet for tidligere tiders undervisningsindhold først og fremmest skal definere læringsmål for de enkelte uddannelser eller uddannelsesmoduler: Hvad kan eleven eller den studerende forventes at kunne, når han/hun har gennemført denne uddannelse eller dette modul? Man definerer en profil for den kandidat, som man uddanner. Dermed er det enklere at tilrettelægge eksaminer eller tests, hvor den enkelte skal dokumentere, at han/hun faktisk har tilegnet sig den viden eller opnået det færdighedsniveau, som var

\footnotetext{
6 Dette gælder selvsagt for alle fag; et andet eksempel på, at elever bliver sat på en opgave, som de reelt ikke kan løse, er når 4. klasseelever i folkeskolen skal lave interviewundersøgelser uden det mindste kendskab til eller forståelse for samfundsvidenskabelig metode, herunder statistik. Man bilder faktisk børnene ind, at de kan løse en opgave, hvor dette slet ikke er tilfældet, og hvor de måske ville være meget bedre tjent med en helt anden og for dem mere realistisk opgavetype.
} 
målet, og dermed er det også mindre kompliceret at sammenligne uddannelseselementer og overføre merit fra en uddannelse til en anden inden for det samme land eller mellem forskellige lande. Når det gælder den sprogligt-kulturelle viden og de kommunikative færdigheder, udgør den fælles europæiske referenceramme et rigtig godt fundament for sådanne sammenligninger.

\section{Livslang laring}

Den europæiske referenceramme kan dog ikke blot anvendes inden for skolesystemerne; den er mindst lige så anvendelig, når man skal dokumentere viden og færdigheder, som man har lært eller tilegnet sig uden for de formelle systemer. Det enkelte menneske kan være opvokset $\mathrm{i}$ flersprogede familier, have boet, studeret eller arbejdet i udlandet eller på anden vis have tilegnet sig kommunikative kompetencer, som de ikke formelt "har papir på". Hidtil har dette ikke kunnet anerkendes eller blive dokumenteret, og der har måske heller ikke været så stort behov for det, som man kan forestille sig der vil være i fremtiden. Med et mere og mere mobilt arbejdsmarked på tværs af landegrænser, sprog og kulturer vil flere mennesker i fremtiden beherske sådanne kompetencer og også få brug for at kunne dokumentere dem, eksempelvis i en ansættelsessituation. Det er derfor vigtigt, at der udvikles systemer, som kan gøre det muligt at dokumentere sådanne kompetencer. Der er med andre ord behov for en europæisk sprogportefølje, ${ }^{7}$ hvori den enkelte kan dokumentere både det, som han/hun har lært eller tilegnet sig inden for det formelle skolesystem, og det, som han/hun har tilegnet sig på anden vis.

\section{Partielle færdigheder}

Nogle vil måske have behov for at udvikle partielle færdigheder i tilknytning til deres uddannelser eller senere hen i tilknytning til deres arbejdssituation, jf. 1.2 ovenfor. Ved at skelne mellem de forskellige færdighedsområder, som det er tilfældet i skema 3 i 2.2 ovenfor, kan den europæiske referen-

7 Jf. http://culture2.coe.int/portfolio/inc.asp?L=E\&M=\$t/208-1-0-1/main_pages/ welcome.html. Endvidere har European Language Council / Conseil Européen pour les Langues udviklet en sprogportefølje for højere uddannelse, som i øjeblikket foreligger på engelsk og fransk. Den vil i løbet af 2003 blive udviklet i en dansk udgave på Handelshøjskolen i Århus. 
ceramme også bruges til at differentiere, fx mellem færdighedsniveauer i sprogproduktion og -reception eller mellem færdighedsniveauer i talt over for skrevet sprog. En dansk ingeniør har brug for at kunne tale med kolleger eller samarbejdspartnere $\mathrm{i}$ andre lande og kulturer; han skal altså beherske den mundtlige interaktion op til et vist niveau, men har kun i begrænset omfang behov for læse- og skrivefærdigheder. En studerende eller forsker har måske behov for at kunne læse faglitteratur på et fremmedsprog uden nødvendigvis at have brug for at kunne skrive selv på avanceret niveau $(\mathrm{C} 2)$ eller kunne interagere mundtligt på det pågældende sprog.

For begge disse eksempler gælder, at den enkelte (ingeniør eller forsker) har brug for (at kunne dokumentere) sine kompetencer på nogle, men ikke alle færdighedsområder. Der bør derfor udvikles materiale, som gør det muligt for den enkelte at teste sine nuværende niveauer og at udvikle og tilegne sig yderligere færdigheder på de områder, hvor det er påkrævet. Sådant materiale kan naturligvis indgå i kurser af forskellig art, men kan også være materiale, der er beregnet på autonom læring. Sidstnævnte vil som oftest være tilgængeligt i en elektronisk form; og dette vil helt sikkert være tilfældet for størstedelen af det i fremtiden.

\section{DIALANG}

DIALANG-systemet, ${ }^{8}$ som vil blive introduceret uden for projektgruppens snævre kreds i 2003, er et webbaseret diagnostisk testsystem, som kan teste lytte-, læse- og skrivefærdigheder på 14 europæiske sprog. ${ }^{9}$ DIALANG er udviklet $i$ et samarbejde mellem en række europæiske universiteter og er det største enkeltprojekt, der nogensinde er blevet finansieret af EU Kommissionen (SOKRATES/LINGUA, Generaldirektoratet for Uddannelse og Kultur).

DIALANG har krævet et stort udviklingsarbejde både teknologisk og med hensyn til diagnostisk testteori og implementeringen heraf. ${ }^{10}$ Når

\footnotetext{
8 Jf. http://www.dialang.org/english/index.html og http://www.fu-berlin.de/elc/en/ dialang.html

9 Dansk, engelsk, finsk, fransk, græsk, islandsk, irsk, italiensk, nederlandsk, norsk, portugisisk, spansk, svensk og tysk.

10 Jf. litteraturhenvisningerne i http://www.coe.int/T/E/Cultural_Co-operation/education/Languages/Language_Policy/Common_Framework_of_Reference/ cadre.asp\#TopOfPage, ikke mindst appendix $\mathrm{C}$ vedr. DIALANG.
} 
52

det foreligger, vil det være tilgængeligt på Internettet og vil derfor gøre det muligt for enhver med netadgang at teste sin viden og sine færdigheder, hvad enten de er lært inden for eller uden for det formelle uddannelsessystem, jf. afsnit 3 og 4 ovenfor.

Man kan vælge, inden for hvilket sprog man vil have sine færdigheder testet, og hvilket sprog man ønsker sine instruktioner på. En dansker, som vil teste sine færdigheder i portugisisk, kan altså vælge portugisisk som testsprog, men dansk som instruktionssprog.

I den konkrete testsituation vil systemet derefter bede den enkelte angive det niveau, som han/hun mener, han/hun befinder sig på. Igennem testforløbet tilpasser systemet herefter testspørgsmålene til den enkeltes faktisk niveau (såkaldt adapted testing ${ }^{11}$ ). Det betyder altså reelt ikke noget, at man har vurderet sine egne færdigheder for lavt eller for højt fra begyndelsen. Systemet trækker på en database af testelementer, som er kategoriseret inden for de forskellige færdigheder og de forskellige niveauer i den europæiske referenceramme. Når testen er afsluttet, får testpersonen sin personlige respons med angivelse af færdighedsniveauer.

Systemet har mange forskellige anvendelsesmuligheder. For det første kan enhver jo teste sit eget niveau i fremmede sprog - for sjov eller for alvor; og på baggrund af testresultaterne kan den enkelte herefter vælge kurser eller uddannelsesmoduler, som passer til vedkommende. Her vil det naturligvis være en fordel, at kursusudbydere også har beskrevet deres kursusniveau i relation til den fælles europæiske referenceramme. Dette gælder både for kurser, der består af egentlig undervisning, og for kurser, som man arbejder selvstændigt med.

For det andet kan undervisere bruge DIALANG til at vise elever / studerende, at de faktisk har flere sproglige ressourcer, end de som oftest selv går og tror. Hvis man eksempelvis er ved at lære tysk, kan man sikkert godt forstå eller læse lidt nederlandsk; hvis man er dansk, norsk eller svensk, kan man forstå og interagere mundtligt med mennesker, der taler et af de andre to sprog. Det samme gælder forholdet mellem italiensk og spansk; i det hele taget kan systemet bruges til at vise, at hvis man har opnået et vist niveau inden for et sprog i en sprogfamilie, er det meget lettere at lære det næste og det næste igen (fx romanske, slaviske eller germanske sprog).

11 Jf. fx Chalhoub-Deville (ed.) 1999. 
Endelig kan man naturligvis bruge DIALANG til at demonstrere, at den enkelte gør fremskridt ved fx at teste i begyndelsen og slutningen af et kursus eller modul.

Selv om der ligger mange testelementer i databasen, når systemet bliver gjort offentligt tilgængeligt i 2003, vil det være nødvendigt at vedligeholde det og forny basen, hvis den skal kunne anvendes over en længere årrække. For det første vil eksempler blive forældede og pludselig virke underlige (brug af navne på personer, organisationer, mv.). For det andet kan man forestille sig, at personer, der tager den samme test flere gange, efterhånden genkender spørgsmålene, også selv om den indbyggede randomisering af testelementerne og den nævnte adapted testing skulle forebygge, at en person i realiteten tager den samme test to gange.

I den sammenhæng skal det naturligvis også nævnes, at testen ikke kan anvendes som en formel eksamen, fordi den trækker på en database, som man med mange testforsøg vil kunne gøre sig bekendt med, og man derfor ikke ville dokumentere sit reelle sproglige niveau i en 


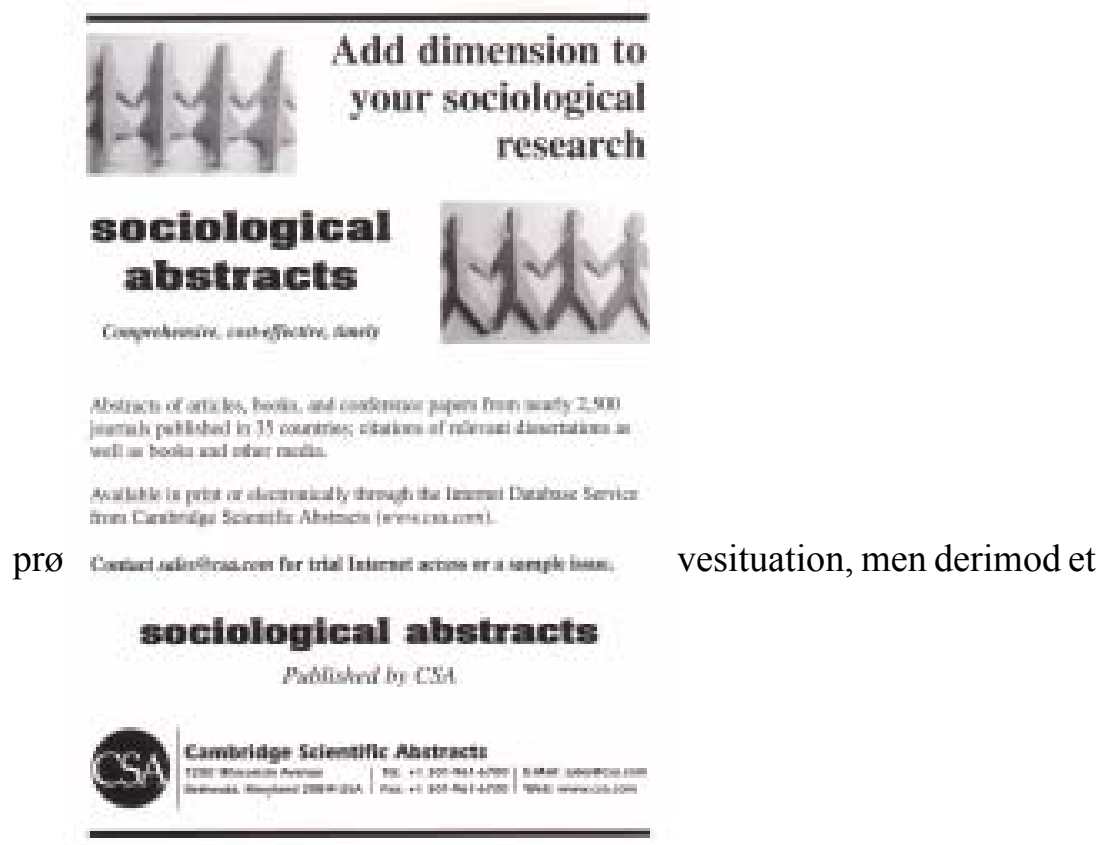

efter al sandsynlighed kunstigt forbedret niveau.

En svaghed ved DIALANG i forhold til den fælles europæiske referenceramme er, at man i den foreliggende udgave ikke kan teste mundtlig sprogfærdighed (talt produktion) og interaktion. Dette skyldes først og fremmest, at teknologien endnu ikke er robust nok til at håndtere mundtligt input til det webbaserede system, ikke mindst talegenkendelsesteknologien; men der er ingen tvivl om, at det kun er et spørgsmål om tid, før teknologien er til stede, og at det til den tid er et spørgsmål om at få finansieret udvidelsen af DIALANG systemet til også at omfatte talt input.

\section{Perspektivering}

De to indbyrdes forbundne systemer, som er omtalt her, den fælles europæiske referenceramme og DIALANG, er begge udtryk for europæiske nyudvikling inden for undervisning i samt tilegnelse og testning af 
kommunikative kompetencer. De er begge betingede af et højtprioriteret politisk ønske om at muliggøre realiseringen af den europæiske sprogpolitik, som vil bibeholde og udvikle Europa som et flersproget og flerkulturelt samfund. Den øgede mobilitet og den øgede integration mellem mange forskellige sprog og kulturer nødvendiggør imidlertid, at de enkelte borgere, ikke kun en mindre elite, udvikler deres fremmedsproglige færdigheder.

Selv uden at have så høje politiske mål for øje, er der meget at hente både for den enkelte lørner og for den enkelte underviser eller kursustilrettelægger. Med udviklingen inden for IT, sprog og læring gennem de seneste år er der ikke tvivl om, at en fælles referenceramme vil være et godt værktøj. Som ikke-fagkyndig lørner kan man, hvis referencerammen bliver implementeret, få adgang til undervisningsmateriale til selvstudium og tests i elektronisk form (CD-ROM eller via Internettet), hvor færdighedsniveauet er klart defineret i forhold til en kendt standard. PC'en kan dermed udgøre et godt supplement til de eksisterende kurser, hvis man ikke har mulighed for at opholde sig i det land og den kultur, hvor sproget bliver brugt.

Det gælder for alle former for kurser, hvad enten der er tale om klasseundervisning eller autonom læring, at niveauinddelingen bliver meget mere gennemskuelig for den enkelte lørner. Han/hun kan lettere forstå, hvad der kræves som indgangsniveau, og hvilket niveau man kan forvente at opnå ved afslutningen af forløbet.

For kursustilrettelæggere og undervisere er der en fælles referenceramme, inden for hvilken de dels kan definere deres eget materiale, dels kan vurdere andres. Det gør både materialevalg og samarbejde på tværs af institutioner i ind- og udland meget nemmere, ligesom det gør det meget enklere at administrere meritoverførsler.

Endelig vil porteføljetanken kunne synliggøre en mængde tavs viden og uudnyttede ressourcer i form af kommunikative kompetencer og færdigheder både for dem, som skal arbejde med fremmede sprog og kulturer som deres egentlige genstandsområde, og dem, som skal bruge dem som basiskompetencer i deres arbejds- eller fritidsliv.

\section{Referencer}

Chalhoub-Deville, Micheline (ed.) 1999 Issues in Computer-Adaptive Testing of Reading Proficiency. Cambridge, UK: University of Cambridge Local Examinations Syndicate and Cambridge University Press.

http://www.coe.int/T/E/Cultural_Co-operation/education/Languages/Language_Policy/ Common_Framework_of_Reference/cadre.asp\#TopOfPage 


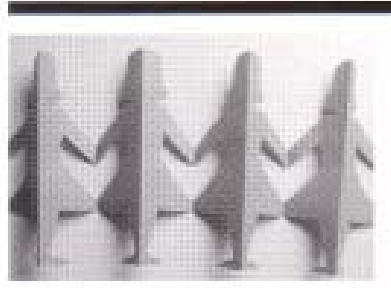

\section{Add dimension to your sociological research}

\section{sociological abstracts}

Comprehensive, cost-effective, timely

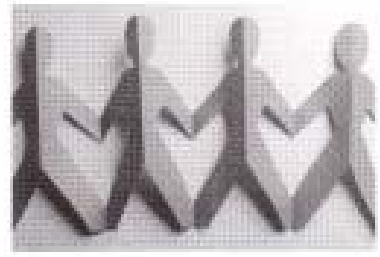

Abstracts of articles, books, and conference papers from nearly 2,500 journals published in 35 countries; citations of relevant dissertations as well as books and other media.

Available in print or electronically through the Intemet Database Service from Cambridge Scientific Abstracts (www.csa.com).

Contact sales@esa.com for trial Internet access or a sample issue.

\section{sociological abstracts}

Published by CSA 